Journal of Business and Management Studies (JBMS)

ISSN: 2709-0876

DOI: $10.32996 / \mathrm{jbms}$

Journal Homepage: www.al-kindipublisher.com/index.php/jbms

\title{
The Relationship between Transformational Leadership and Innovation and Creativity in Management to Improve Employees' Academic Performance at Sohar University
}

\author{
Al-Saidi Ibtisam Harib Salim ${ }^{1} 8$ (D) $\triangle$ and Dr. Abd Wahab Zakaria² 8 (D) \\ ${ }^{1}$ PhD Student, International Islamic University Malaysia (IIUM), Sultanate of Oman \\ ${ }^{2}$ Assistant professor, International Islamic University Malaysia (IIUM), Selangor, Malaysia \\ $\triangle$ Corresponding Author: Al-Saidi Ibtisam Harib Salim, E-mail: alsaidiibtisam@gmail.com
}

\author{
ARTICLE INFORMATION \\ Received: June 08, 2021 \\ Accepted: August 01, 2021 \\ Volume: 3 \\ Issue: 2 \\ DOI: $10.32996 / j b m s .2021 .3 .2 .8$
}

\section{KEYWORDS}

Transformational Leadership, Innovation, creativity, Employees' Academic Performance, Sohar University, Sultanate of Oman

\section{ABSTRACT}

This study investigated the relationship between transformational leadership practices and norms and employees' performance at Sohar University in the Sultanate of Oman. This research is based on the fact that traditional methods of leadership handicap the development of modern leadership practices in Sohar University in particular and in Oman in general. This study may contribute to some significant solutions to the extant literature especially in that transformational leadership practices could be of great value if they are supported by modern techniques and high training skills for employees. The present paper adopts qualitative research method. Questionnaire was used as a research instrument of collecting data. The 5-Point Likert Scale was adopted to help researchers analyze the data. The study concludes that Transformational leadership skills are very essential for high-ranking leaders to acquire in Sohar University in the Sultanate of Oman. The study also finds that transformational leadership skills are very essential for high-ranking leaders to acquire in Sohar University in the Sultanate of Oman. Having conducted statistical analysis, this study draws some conclusions and suggests some recommendations for transformational leadership and its use in developing administrative creativity and improving job performance among Sohar University employees. This can be summarized as follows. First, transformational leadership skills are very essential for high-ranking leaders to acquire in Sohar University in the Sultanate of Oman. second, transformational leaders with outstanding leadership skills are found astonishingly effective in managing and leading those working under them. Third, employees are found to be greatly affected by their leaders in respect with academic and managerial activities and finally the study found that Universities in the Sultanate of Oman do not pay special attention to transformational leadership skills, which this negatively affects the quality and credibility of teaching.

\section{Introduction}

Leadership is the spirit of the contemporary management and the focus of its activity. Organizations began to pay special attention to select the most qualified and appropriate leaders to engage with the management process. An administrative leadership with a regulatory and creative environment requires different methods designed to develop the individual creative abilities and instil the administrative elements of creativity in the organizations away from the traditional leadership. A leadership with a clear vision focuses on the organization's objectives and the way to achieve those objectives. These developments and rapid changes resulted in a new kind of leadership called "Transformational Leadership" as formulated by the American political scientist (Piccolo, 2006).

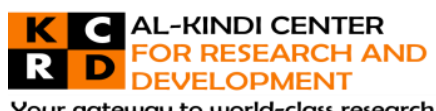

Your gateway to world-class research

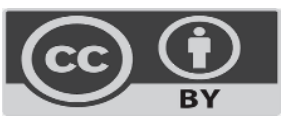

Published by Al-Kindi Center for Research and Development. Copyright (c) the author(s). This open access article is distributed under a Creative Commons Attribution (CC-BY) 4.0 license 


\subsection{Research problem}

The researcher noticed, through her work at Sohar University, that some employees complain about the managers' behavior due to the ambiguity of innovation for the academic and administrative leaders and their followers. He investigated the difficulty that leaders face in dealing with the changes that help improve job performance. Therefore, the researcher distributed a survey to 30 university employees about leadership in the university. In addition, interviews were conducted with a number of administrative and academic leaders. This study claims that the university academic and administrative leaders lack the transformational leadership qualities as the university still follows the practices of traditional management. Such leaders insist on speaking without listening and by making decisions without the employee's participation. Moreover, they refuse to empower employees and increase their delegation of authority. This in fact reduces the opportunities of teachers to become transformational leaders, which negatively affects job performance, capacity of university employees and achievement of goals efficiently and effectively.

The significance of this study lies in its valuable topic that investigates transformational leadership behavior and its relationship with the academic staff at Sohar University in the Sultanate of Oman. The findings of this study are of great value for institutes where innovative and creative leaders play an essential role in developing the outcomes of education. This study is a response for many calls encouraging for a new research to investigate the different types of modern transformational leadership in the Sultanate of Oman. This study helps top leadership in Sohar University to be aware of the concept of transformational leadership and how this affects the relationship between transformational leaders and their followers' creativity and innovation. This study also provides Sohar University with some essential feedback about the academic and managerial level of top-management personnel in respect to transformational leadership and its effect on innovation and creativity. This study is limited to the relationship between norms of transformational leadership, creativity and innovation for academic staff at Sohar University. The study also covers a period of time between 2019 to 2020.

\subsection{Literature Review}

PICCOLO (2006) investigated transformational leadership effects on organizational leadership behavior. The author found that mechanisms explaining those effects are still unclear. The study showed that transformational leadership is connected with the ways followers view their professions in respect of Hackman and Oldham's (1976) main job characteristics. The author also showed that transformational leadership relationships were significantly stronger for followers perceiving high-quality leadermember exchange. Over the past two decades, transformational leadership has been developed as one of the most prevalent methods to comprehending leader effectiveness. The theory of transformational leadership is built on the emphasis that specific leader behaviors may stimulate followers to a higher level of thinking (Bass, 1985; Burns, 1978). As articulated by (Bass, 1985, p.19) "appealing to followers' ideals and values, transformational leaders enhance commitment to a well-articulated vision and inspire followers to develop new ways of thinking about problems". In fact, the positive connection between transformational leadership and followers' behaviors is well-documented (Fuller, Patterson, Hester, \& Stringer, 1996; Judge \& Piccolo, 2004; Lowe, Kroeck, \& Sivasubramaniam, 1996).

According to Bass (1985, p: 15), "transformational leaders provide constructive feedback to their followers, convince followers to exhibit extra effort, and encourage followers to think creatively about complex problems". This therefore helps followers to behave in ways which facilitate high levels of task performance. Indeed, the relationship between transformational leadership and essential profession characteristics is pivotal, because those characteristics were remarkably connected to intrinsic motivation as well as goal commitment.

Having introduced and tested a model which used theory of job characteristics as a tool for demonstrating the relationship between transformational leadership and useful profession behaviors, (Bass, 1985, p.14) emphasized that "followers of truly exceptional leaders regarded their jobs as more challenging and important". Transformational leaders are able to manage meaning by utilizing imagery and language to frame followers' profession experiences (Salancik \& Pfeffer, 1978; Smircich \& Morgan, 1982).

\subsection{Creative Management}

Creative management concerns about management study and practice. It draws on the theories of innovative processes and their application at individual, group, organizational and cultural levels. Creative management is in fact correlated with transformational leadership.

\subsection{Principles of Creative Management}

\subsubsection{The universality principle}

Creativity is a potential that exists in all human beings. This rests on theories focusing exclusively on extraordinary innovative talents in science and arts as well as in business. The universality principle, however, is broadly accepted in the educational domain, where intelligence is considered as a universal, though some people show evidence of having superior levels of intelligence than others. 


\subsubsection{The developmental principle:}

Potential creativity becomes actual creativity under appropriate developmental conditions. However, actual creativity declines if a person is restricted in opportunities to show their creativity.

\subsubsection{The environmental principle:}

Environmental characteristics affect the creativity development and manifestation (the developmental principle). Because transformational leaders communicate a compelling challenge and vision of the status quo, employees are estimated to be more open to change (Herold, Fedor, Caldwell, \& Liu, 2008; Oreg \& Berson, 2011). "Transformational leadership has been found to be an important facilitator of employee adaptation" (e.g., Nemanich \& Keller, 2007, p.45).

Transformational leaders are aware of the changes necessary in the corporate and make a vision to guide and perform the changes by motivating and inspiring followers. It was reported that those following transformational leaders have less intention to resist transformation (Oreg \&Berson, 2011), and less cynicism about change (Bommer, Rich, \& Rubin, 2005). It was found that the transformational leadership effect was poor when a company staff's need for leadership was low (Breevaart, Bakker, Demerouti, \& Derks, 2016). If employees are not acknowledged with the employing association, it is uneasy for them to find meaning at work (Pratt \& Ashforth, 2003). In this context, transformational leadership requires more and is supposed to have sturdier effects.

Bommer, Rich and Rubin (2005) examined how transformational leadership inspires employees job crafting by increasing employees adaptability and how employee identification with the corporate affects the effect of transformational leadership. The author(s) demonstrated that transformational leadership was of a direct outcome on seeking resources. The findings also did support the conditional indirect outcomes of transformational leadership on seeking challenges and seeking resources. These findings claim that transformational leadership is more effective in indirectly fostering expansion job crafting through increasing employee adaptability, especially when employees are less identified with the organization. It appears that transformational leaders motivate employees to enrich their profession characteristics by increasing job challenges and job resources.

Piccolo and Colquitt (2006, p.10) argued that "under transformational leadership, employees tend to experience high levels of skill variety, task identity, task significance, autonomy, and feedback". (Bommer, Rich, \& Rubin, 2005) concluded that transformational leadership which is change-oriented is a pivotal antecedent of employee proactivity and adaptability. They also concluded that transformational leadership is effective in enhancing employees' adaptability and thus expansion job crafting when employees are not highly identified with the company.

Bass (1985) and Yukl (1999) reported that transformational leaders motivate their followers to accomplish various performances beyond expectations. This is to be done by transforming followers' beliefs, attitudes, and values as opposed to simply gaining compliance (Bass, 1985; Yukl, 1999a, 1999b). Bass (1985) identified a number of sub-dimensions of transformational leadership. This includes charisma, intellectual stimulation, individualized consideration and inspirational motivation.

It was reported by (Thomas, 2016) that transformational leadership affects employees' job performance. The authors identified five main mechanisms: affective, motivational, identification, social exchange, and justice enhancement. These mechanisms are consistent with established psychological and social theories. To conduct meta-analysis, authors involved 600 samples in testing these mechanisms. The findings showed that transformational leadership was associated with variables representing these mechanisms, which in turn were connected to non-self-report measures of employees' duty performance, innovative behavior and citizenship behavior. There have been many explanatory mechanisms having explained the positive effects of transformational leadership on job performance. Understanding mechanisms of transformational leadership is pivotal for both researchers and practitioners, which thus enhances employees' job performance and satisfaction.

\subsection{Nature of transformational leadership}

Transformational leadership inspires followers to believe in the leader's visualization beyond their own self-interest (Bass, 1985; Burns, 1978). Transformational leadership includes four main components: inspirational motivation, idealized influence, individualized consideration and intellectual stimulation (Bass, 1985; Bass \& Avolio, 1993). Idealized influence exhibits charisma and confidence, arousing loyalty and strong emotions from followers. Inspirational motivation involves communicating high expectations, organizational goals, and convincing followers of the significance of the desired goals. Intellectual stimulation involves encouraging inventive ways of thinking by transforming existing norms and routines. Individualized consideration concerns the followers' individual needs. Overall, transformational leadership gives followers reasons and meaning to expend efforts in their professions (Grant, 2012). Followers of transformational leaders are more likely to approve the organizational tasks (Caillier, 2014a, 2014b; Colbert, Kristof-Brown, Bradley, \& Barrick, 2008). "These positive effects of TFL exist at not only the individual level, but also the team, unit, and organizational levels" (Searle \& Barbuto, 2013, p:24). 
From an internal management perspective, transformational leadership may affect followers' profession motivation, experiences, and value system. From an external management perspective, transformational leadership can influence employees' broader work environment and social exchanges. These five explanatory mechanisms are elaborated as follows. The affective mechanism suggests that "transformational leaders promote the positive affective well-being of followers and that enhanced affective wellbeing promotes job performance in turn" (Thomas, 2016, p.21). This mechanism is best elaborated by both "affective events theory" (Weiss \& Cropanzano, 1996) and "expectancy theory" (Vroom, 1964). First, "affective events theory" argues that the external environment sturdy defines employees' affective experiences at workplace. "Employees experience a variety of positive and negative work events, which give rise to positive and negative affective experiences" (Ohly \& Schmitt, 2015, p:17). Transformational leaders, for instance, improve followers' positive temper (Bono \& llies, 2006), and their positivity is transmittable and caught by followers (Bono, Foldes, Vinson, \& Muros, 2007). Indeed, some scholars have viewed transformational leadership as a process of transmitting positive effects from leaders to their followers (Bommer, Rich, \& Rubin, 2005; Walter \& Bruch, 2009).

Affective events theory argues that when leaders exhibit positive behaviors such as encouraging followers and considering their needs, the followers' positive effect in the workplace is most probably to enhance. "As job satisfaction and affective organizational commitment reflect employees' positive feelings about their jobs and organizations" (Harrison, Newman, \& Roth, 2006, p: 28).

The motivational mechanism proposes that transformational leaders motivate and inspire followers to feel confident in accomplishing their professional tasks by having a strong will to devote time and dedicate effort to their work duties. In fact social cognitive theory (Bandura, 2001, 2006) is of a informative nature. It emphasizes that individuals usually strive to be agentic by trying to make things happen through their actions. The theory stresses that "self-efficacy, or the confidence to do well in a domain, is the key to determining whether an individual can successfully shape reality in the way he or she wants" (Thomas, 2016). Those employees who have greater self-efficacy have outstanding confidence in their capability to do well which in turn encourage them to work hard and confront setbacks. The identification mechanism suggests that "followers of transformational leaders are inspired by and personally identify with the leaders or their values". In turn, strengthened identification becomes one of the main sources of inspiration for followers to work harder. "Social identification theory" is particularly relevant here. "Identification is the integration of a person's value system with that of another entity" (Vignoles, Regalia, Manzi, Colledge, \& Scabini, 2006). Identification appears when individuals internalize the beliefs and values of the other entity (Hornsey \& Hogg, 2000). The theory suggests that an individual's strengthened identification with a goal is connected to a stronger motivation to achieve well for that goal, because the person is ready to exert efforts to accomplish those ideals on behalf of that goal (Meyer, Becker, \& Van Dick, 2006).

As transformational leaders show a set of positive behavior seen as charismatic and motivating, followers are more likely to identify with the leader's principles or with what they recognize the leader as representing (Ashforth, Harrison, \& Gorley, 2008; Ashforth \& Mael, 1989). This "entails not only a reduced gap between what the leader and the follower see as ideal, but also a sense of personal endorsement and admiration of the transformational leader's value and behavior" (Thomas, p.24). Having conducted meta-analytical data gathered from 600 articles (Thomas, 2016) showed that five theory-driven mechanisms assist in elaborating the TFL effects on performance outcomes. Each of these five mechanisms is outstanding. The affective mechanism concentrates on the positive emotional experiences of being led by transformational leaders. The motivational mechanism concentrates on the effects of transformational leadership on employees' excitement and confidence in doing their work activities. The identification mechanism demonstrates the effect of transformational leadership on employees' beliefs and value. The social exchange mechanism emphasizes the social exchange quality between followers and transformational leaders (and the organization). The justice enhancement mechanism emphasizes on the social keys which are created by transformational leadership around resource allocation in the workplace. This thus affects employees' confidence in leaders and their profession efforts.

\subsection{Leadership Theories}

\subsubsection{Great-Man Theory}

MacGregor(1986) claimed in his "great man theory" that leaders are naturally born and that only those men endowed with outstanding potentials are able to become leaders. Carlyle stressed that great men were born, not made.

MacGregor (1986, p.21) claimed that "the actions of the event-making man influenced the course of events, which could have been much different, had he not been involved in the process". Great-Man Theory rests on the assumption that "the consequences of outstanding capacities of intelligence, will and character rather than the actions of distinction" (ibid, p.29). Despite the strengths of Great-Man Theory, some authors (Hitler \& Napoleon) criticized the theory in that it was morally flawed and in that these great men became irrelevant. MacGregor (2003, p:19) argued that "the passing years have given the coup de grace to another force the great man who with brilliance and farsightedness could preside with dictatorial powers as the head of 
a growing organization but in the process retarded democratization". Leadership theory progressed from the view that leaders are born and are destined by nature to be a pivotal role at a particular time to a reflection of specific traits envisaging a potential for leadership.

\subsubsection{Trait Theory}

Born leaders were gifted with specific physical qualities and personality features distinguishing them from non-leaders. Trait theories pay no attention to the assumptions about whether leadership traits are acquired or genetic. Ekvall and Arvonen (1991) identified emergent traits heavily dependent upon heredity as intelligence, self-confidence, attractiveness height, effectiveness traits and self-confidence.

\subsubsection{Contingency Theories (Situational)}

The theories of contingency suggests that there is no leadership style being precise as a stand-alone as the leadership style employed depends upon different factors such as the quality, followers' conditions or a number of other related variables. "According to this theory, there is no single right way to lead because the internal and external dimensions of the environment require the leader to adapt to that particular situation" (Greenleaf, 1977, p.26). In most cases, real leaders do not try to change the dynamics and environment where employees play an essential part within the organization. Theories of contingency are a category of behavioral theory challenging that there is no proper way of organizing/leading that the style of leadership is operative in some circumstances might not be effective(Greenleaf, 1977).

\subsubsection{Style and Behavior Theory}

The style theory acknowledges the importance of specific necessary leadership techniques that work as enabler for a leader performing an act while drawing its parallel with previous capacity of the leader. The theory assumes that each individual has a distinct special style of leadership with which s/he feels contented.

\subsubsection{Transactional Theory}

The transactional leadership was described as "that in which leader-follower associations were grounded upon a series of agreements between followers and leaders" (House \& Shamir, 1993, p.19). The transactional theory was built on "reciprocity where leaders not only influence followers but are under their influence as well" (House \& Shamir, 1993, p.19). Some studies demonstrated that transactional leadership illustrate a discrepancy with regard to the leader's level, action and the nature of their relationships with their followers.

\subsubsection{Transformational Theory}

Transformational leadership is different from the rest of the previous and contemporary theories in that it entails followers' involvement in processes or activities which are related to personal factors towards the organization and a course providing specific superior social dividend. The transformational leaders usually raise the morality and motivation of both followers and leaders (House \& Shamir, 1993). li was reported that transformational leaders "engage in interactions with followers based on common values, beliefs and goals" (House \& Shamir, 1993, p.31). This affects the performance leading to the attainment of purpose. This theory in fact conforms the Maslow's (1954) higher order theory of needs.

\subsection{Research Methodology}

This study adopts descriptive research method to describe a new phenomenon and to quantitatively interpret the data by collecting accurate information about the problem. This investigation can be done by accurately analyzing the study problem. Adopting descriptive research method helps researcher to investigate the role of transformational leadership in promoting employees' administrative creativity at Sohar University in the Sultanate of Oman.

\subsection{Data Analysis}

This chapter contains an overview of the study results by answering the study questions and reviewing the most prominent results of the questionnaire, by analyzing its items to identify the "relationship between transformational leadership, administrative innovation and improvement of job performance among Sohar University employees in the Sultanate of Oman". Therefore, statistical treatments of the questionnaire data were conducted using the Statistical Package for Social Science (SPSS) to get the study results in this chapter. The study criteria adopted are: (Statistics Center - Abu Dhabi, 2017: 27)

The length of the cells in the 5 -Point Likert Scale was determined by calculating the range between the scale degrees $(5-1=4)$ and dividing the range by the scale largest value to get the length of the cell, i.e. $(4 / 5=0.80)$. After that, this value was added to the scale lowest value (the beginning of the scale is 1) in order to determine the upper limit of this cell. The following table shows the length of the cells. 
Table: A:

The study criteria

\begin{tabular}{|c|c|c|}
\hline Arithmetic mean & Relative weight & Degree of agreement \\
\hline From 1-1.80 & From 20\%-30\% & Strongly disagree \\
\hline More than 1.80-2.60 & More than 36\%- 52\% & Disagree \\
\hline More than 2.60- 3.40 & More than 52\%- 68\% & Neither agree nor disagree \\
\hline More than 3.40- 4.20 & More than 68\%- 84\% & Agree \\
\hline More than 4.20- 5 & More than 84\%- 100\% & Strongly agree \\
\hline
\end{tabular}

The researcher relied on arranging the arithmetic means at the level of the questionnaire topics/fields and items in each field in order to explain the study results and evaluate the response level. The researcher determined the degree of agreement according to the study criteria.

Question 1: To what extent are the leaders' characteristics and features of transformational leadership available/exist with their dimensions (Idealized influence, Individualized consideration, Inspirational motivation and Intellectual stimulation) at Sohar University leaders in the Sultanate of Oman? To answer this question, the arithmetic mean, standard deviation, relative weight and order were used, as illustrated in the following table.

Table (B)

Arithmetic mean, standard deviation, relative weigh/valuet and order to identify the leaders' characteristics and features of transformational leadership with its dimensions (Idealized influence, Individualized consideration, Inspirational motivation and Intellectual stimulation) at Sohar University in the Sultanate of Oman?

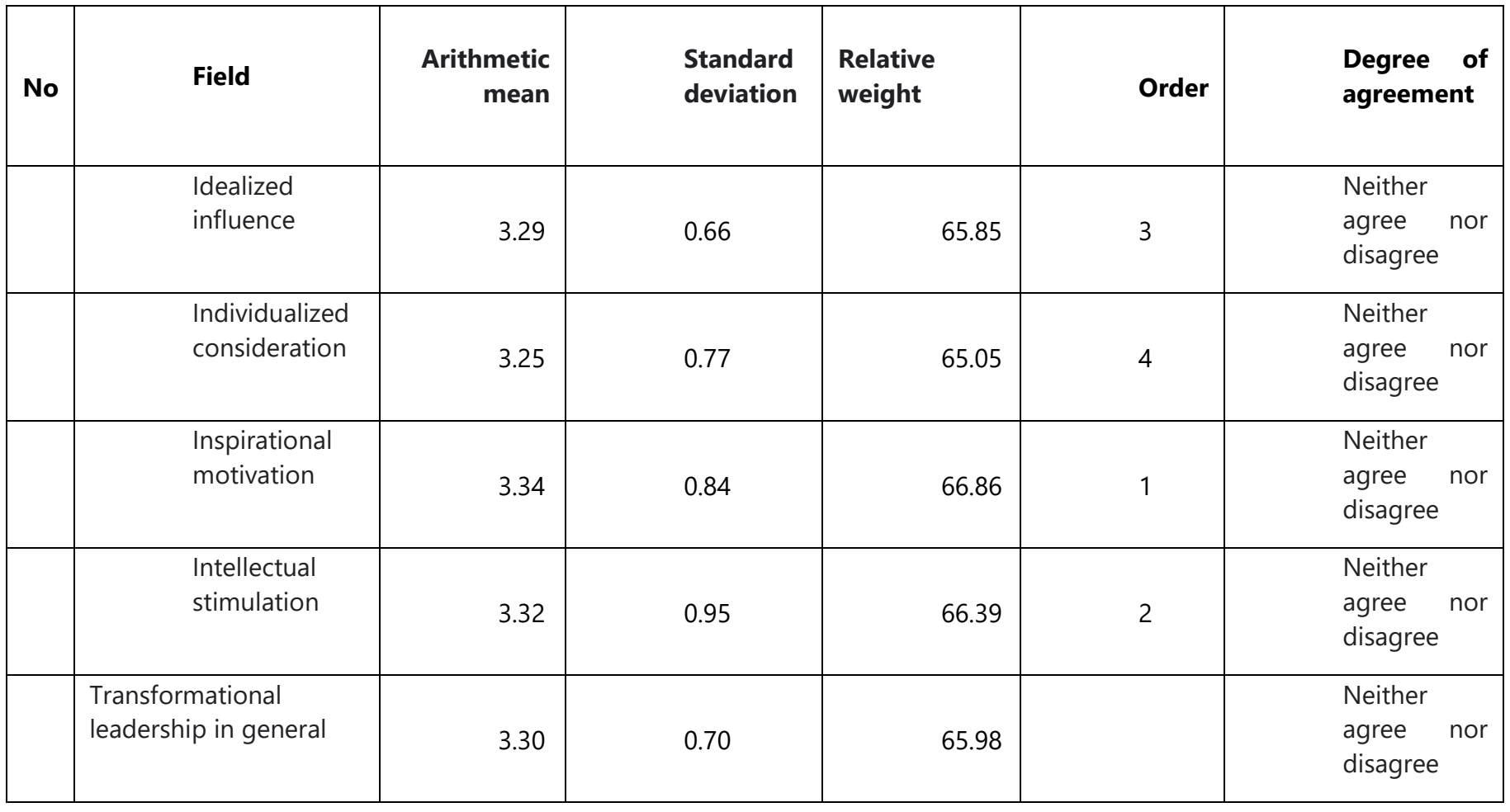


Table (B) shows that the arithmetic mean of all items is 3.30 and the relative weight is $65.98 \%$, which means that the respondents neither agree nor disagree on the transformational leadership items in general. The table also illustrates that the first field "idealized influence" is in third place, with a relative weight of $65.85 \%$. This is attributed by the researcher to the fact that the administrative department heads are characterized by their high professional ethics, staff respect and providing a stable environment. In addition, department heads are characterized by their high capacity to persuade their employees and their intellectual and administrative skills. This was confirmed by previous studies such as (Bruns, 1985), which concluded that the idealized influence has a significant impact and relative weight on job performance, creativity and innovation (Herold, Fedor, Caldwell, \& Liu, 2008).

The second field, Individualized consideration, is in fourth place, with a relative weight of $65.05 \%$. It is the less used dimension of transformational leadership; due to the fact that the department heads did not take care of their employees' needs and efforts and did not support their achievements. This was confirmed by (Bass, 1985) all of which were for Individualized consideration, with a medium relative weight.

On the other hand, (Breevaart, Bakker, Demerouti, \& Derks, 2016) found that the idealized influence, intellectual stimulation and inspirational motivation were of a significant relative weight than Individualized consideration. The third field, inspirational motivation, is in the first place, with a relative weight of $66.86 \%$. The researcher attributes this to present the department heads as a successful example to follow and to encourage employees to work in a spirit of cooperation. This provides administrative tasks in the sense of teamwork to achieve more than they expect by raising the spirit of enthusiasm among the employees.

Moreover, each department head is an example of success so that every employee follows (them) and illustrates their achievements to their subordinates. Regarding what has been aforementioned, this study agrees with other studies, i.e. (Pratt $\&$ Ashforth, 2003), and (Bommer, Rich, \& Rubin, 2005).

Finally, the fourth field, Intellectual stimulation, is in second place, with a relative weight of $66.39 \%$. The researcher attributes this to the fact that the department heads encourage their employees to rethink and search for new ways to solve problems, especially urgent ones. Thus, the researcher agrees with (Thomas, 2016), and (Grant, 2012) since these studies confirmed that the intellectual stimulation had a great relative weight.

\section{Analysis of "idealized influence" items:}

The arithmetic mean, standard deviation, relative weight and order were used to determine the degree of agreement. The results are shown in table $(C)$.

\section{Table (C):}

Arithmetic mean, standard deviation, relative weight, and order for each item of "idealized influence".

\begin{tabular}{|c|c|c|c|c|c|c|}
\hline & $\begin{array}{l}\text { Sohar University Department Heads are respected } \\
\text { by everyone at work. }\end{array}$ & 3.37 & 0.94 & 67.45 & 4 & $\begin{array}{l}\text { Neither agree } \\
\text { or disagree }\end{array}$ \\
\hline & $\begin{array}{l}\text { Sohar University Department Heads are a good } \\
\text { example for a successful work. }\end{array}$ & 3.25 & 1.11 & 65.10 & 6 & $\begin{array}{l}\text { Neither agree } \\
\text { or disagree }\end{array}$ \\
\hline & $\begin{array}{l}\text { Sohar University Department Heads are calm } \\
\text { during crisis. }\end{array}$ & 3.20 & 1.22 & 63.92 & 10 & $\begin{array}{l}\text { Neither agree } \\
\text { or disagree }\end{array}$ \\
\hline & $\begin{array}{l}\text { Sohar University Department Heads always brag } \\
\text { about their subordinates' work. }\end{array}$ & 3.18 & 1.20 & 63.53 & 11 & $\begin{array}{l}\text { Neither agree } \\
\text { or disagree }\end{array}$ \\
\hline
\end{tabular}




\begin{tabular}{|l|l|l|l|l|l|l|}
\hline & $\begin{array}{l}\text { Sohar University Department Heads prefer the } \\
\text { community interest over their personal interest. }\end{array}$ & 3.10 & 1.37 & 61.96 & 12 & $\begin{array}{l}\text { Neither agree } \\
\text { or disagree }\end{array}$ \\
\hline $\begin{array}{l}\text { Sohar University Department Heads help their } \\
\text { subordinates to overcome the work problems. }\end{array}$ & 3.24 & 1.21 & 64.71 & 7 & $\begin{array}{l}\text { Neither agree } \\
\text { or disagree }\end{array}$ \\
\hline $\begin{array}{l}\text { Sohar University Department Heads underline the } \\
\text { importance of work values, such as honesty and } \\
\text { truthfulness. }\end{array}$ & 3.24 & 1.26 & 64.71 & 8 & $\begin{array}{l}\text { Neither agree } \\
\text { or disagree }\end{array}$ \\
\hline $\begin{array}{l}\text { Sohar University Department Heads underline the } \\
\text { importance of work objectives. }\end{array}$ & 3.37 & 1.30 & 67.45 & 4 & $\begin{array}{l}\text { Neither agree } \\
\text { or disagree }\end{array}$ \\
\hline $\begin{array}{l}\text { Sohar University Department Heads are concerned } \\
\text { with work ethics and values. }\end{array}$ & 3.39 & 1.08 & 67.84 & 3 & $\begin{array}{l}\text { Neither agree } \\
\text { or disagree }\end{array}$ \\
\hline $\begin{array}{l}\text { Sohar University Department Heads have } \\
\text { intellectual and administrative skills. }\end{array}$ & 3.49 & 1.38 & 69.80 & 2 & Agree \\
\hline $\begin{array}{l}\text { Sohar University Department Heads are keen to } \\
\text { strengthen confidence with employees to } \\
\text { overcome work obstacles. }\end{array}$ & 3.24 & 1.32 & 64.71 & 8 & $\begin{array}{l}\text { Neither agree } \\
\text { or disagree }\end{array}$ \\
\hline
\end{tabular}

Table (C) demonstrates the two highest items:

- Item (2) "Sohar University Department Heads have strong personality and self-confidence to encounter everything", is in first place with a relative weight of $73.73 \%$.

- Item (12) "Sohar University Department Heads have intellectual and administrative skills", is in second place with a relative weight of $69.80 \%$.

In line with the table $(C)$, the results show that the researcher believes that the most prominent features of a leader in an institution or university are the great trust between the department head and the employee and his keenness to achieve the university's goals. Therefore, the university's department head and employees respect each other.

It is also clear that Sohar University Department Heads have a strong personality, professional courtesy and respect for employees as well as having qualities befitting their status. Respecting employees enhances their self-confidence and provides them with intellectual and administrative skills, due to the fact that department heads have an open mind and properly address problems, obstacles and challenges.

\section{The lowest two items:}

- Item (7) "Sohar University Department Heads prefer the community interest over their personal interest", is in twelfth place with a relative weight of $61.96 \%$.

- Item (5) "Sohar University Department Heads sacrifice for the good of their subordinates", is in last place with a relative weight of $61.18 \%$.

The researcher attributes this to the fact that the respondents did not agree that the department heads prefer the community interest over their personal interest. Similarly, the department heads did not agree to sacrifice for the good of their subordinates. In general, the researcher believes that the department heads can have idealized influence. These results agree with some studies, such as (Thomas, 2016), and (Ashforth, Harrison, \& Gorley, 2008) which confirmed that the idealized influence items have a significant relative weight.

\subsection{Analysis of "individualized consideration" items}

The arithmetic mean, standard deviation, relative weight and order were used to determine the degree of agreement. 


\subsection{Results are shown in table (D)}

Table (D) Arithmetic mean, standard deviation, relative weight, and order for each of the "individualized consideration" items.

\begin{tabular}{|c|c|c|c|c|c|c|}
\hline No & Item & $\begin{array}{r}\text { Arithmetic } \\
\text { mean }\end{array}$ & $\begin{array}{l}\text { Standard } \\
\text { deviation }\end{array}$ & $\begin{array}{r}\text { Relative } \\
\text { weight }\end{array}$ & Order & $\begin{array}{r}\text { Degree of } \\
\text { agreement }\end{array}$ \\
\hline & $\begin{array}{l}\text { Sohar University Department Heads } \\
\text { are concerned with all subordinates } \\
\text { without exception. }\end{array}$ & 3.35 & 1.18 & 67.06 & 3 & $\begin{array}{l}\text { Neither agree } \\
\text { or disagree }\end{array}$ \\
\hline & $\begin{array}{l}\text { Sohar University Department Heads } \\
\text { appreciate and recognize the } \\
\text { employees' efforts. }\end{array}$ & 3.25 & 1.20 & 65.10 & 5 & $\begin{array}{r}\text { Neither agree } \\
\text { or disagree }\end{array}$ \\
\hline & $\begin{array}{l}\text { Sohar University Department Heads } \\
\text { feel that they are able to perform } \\
\text { their work properly. }\end{array}$ & 3.35 & 1.21 & 67.06 & 2 & $\begin{array}{r}\text { Neither agree } \\
\text { or disagree }\end{array}$ \\
\hline & $\begin{array}{l}\text { Sohar University Department Heads } \\
\text { treat employees respectfully. }\end{array}$ & 3.20 & 1.15 & 63.92 & 7 & $\begin{array}{r}\text { Neither agree } \\
\text { or disagree }\end{array}$ \\
\hline & $\begin{array}{l}\text { Sohar University Department Heads } \\
\text { give advice and instructions to } \\
\text { employees to develop their abilities } \\
\text { to work. }\end{array}$ & 3.25 & 1.32 & 65.10 & 6 & $\begin{array}{r}\text { Neither agree } \\
\text { or disagree }\end{array}$ \\
\hline & $\begin{array}{l}\text { Sohar University Department Heads } \\
\text { recognize the different capabilities } \\
\text { of their subordinates. }\end{array}$ & 3.14 & 1.37 & 62.75 & 8 & $\begin{array}{r}\text { Neither agree } \\
\text { or disagree }\end{array}$ \\
\hline & $\begin{array}{l}\text { Sohar University Department Heads } \\
\text { assist employees in self- } \\
\text { development and growth. }\end{array}$ & 2.94 & 1.29 & 58.82 & 9 & $\begin{array}{r}\text { Neither agree } \\
\text { or disagree }\end{array}$ \\
\hline & $\begin{array}{l}\text { Sohar University Department Heads } \\
\text { appreciate the employees' efforts. }\end{array}$ & 3.33 & 1.21 & 66.67 & 4 & $\begin{array}{r}\text { Neither agree } \\
\text { or disagree }\end{array}$ \\
\hline & $\begin{array}{l}\text { Sohar University Department Heads } \\
\text { work to meet the needs and desires } \\
\text { of employees. }\end{array}$ & 3.45 & 1.27 & 69.02 & 1 & Agree \\
\hline
\end{tabular}

\subsection{Table (D) demonstrates the highest two items:}

- $\quad$ Item (9) "Sohar University Department Heads work to meet the needs and desires of employees", is in first place with a relative weight of $69.02 \%$. 
- $\quad$ Item (3) "Sohar University Department Heads feel that they are able to perform their work properly", is in second place with a relative weight of $67.06 \%$.

The researcher attributes this to the fact that department heads are keen to meet the needs and desires of employees since they feel that they are able to perform their work effectively.

\subsection{The lowest two items:}

- Item (6) "Sohar University Department Heads recognize the different capabilities of their subordinates", is in eighth place with a relative weight of $62.75 \%$.

- Item (7) "Sohar University Department Heads assist employees in self-development and growth", is in the last place with a relative weight of $58.82 \%$.

The researcher attributes this to the fact that the department heads did not sufficiently recognize the subordinates' abilities to develop themselves.

In general, the present study argues that the department heads are characterized by the features of (individualized consideration). Thus, this study is consistent with the study by (Greenleaf, 1977) and (Meyer, Becker, \& Van Dick, 2006).

\subsection{Analysis of "inspirational motivation" items:}

The arithmetic mean, standard deviation, relative weight and order were used to determine the degree of agreement. The results are shown in table $(\mathrm{E})$.

Table (E) Arithmetic mean, standard deviation, relative weight, and order for each items of "inspirational motivation".

\begin{tabular}{|c|c|c|c|c|c|c|}
\hline No & Item & $\begin{array}{l}\text { Arithmetic } \\
\text { mean }\end{array}$ & $\begin{array}{l}\text { Standard } \\
\text { deviation }\end{array}$ & $\begin{array}{l}\text { Relative } \\
\text { weight }\end{array}$ & Order & $\begin{array}{l}\text { Degree of } \\
\text { agreement }\end{array}$ \\
\hline & $\begin{array}{l}\text { Sohar University } \\
\text { Department } \\
\text { Heads talk about } \\
\text { the university } \\
\text { future } \\
\text { optimistically and } \\
\text { excitedly. }\end{array}$ & 3.31 & 1.21 & 66.27 & 4 & $\begin{array}{l}\text { Neither } \\
\text { agree or } \\
\text { disagree }\end{array}$ \\
\hline & $\begin{array}{r}\text { Sohar University } \\
\text { Department } \\
\text { Heads set effective } \\
\text { work standards. }\end{array}$ & 3.18 & 1.32 & 63.53 & 8 & $\begin{array}{l}\text { Neither } \\
\text { agree or } \\
\text { disagree }\end{array}$ \\
\hline & $\begin{array}{l}\text { Sohar University } \\
\text { Department } \\
\text { Heads take } \\
\text { advantage of the } \\
\text { opportunities to } \\
\text { upgrade the } \\
\text { university. }\end{array}$ & 3.51 & 1.36 & 70.20 & 2 & Agree \\
\hline & $\begin{array}{r}\text { Sohar University } \\
\text { Department } \\
\text { Heads are keen to } \\
\text { constantly } \\
\text { encourage } \\
\text { subordinates to } \\
\text { do their jobs. }\end{array}$ & 3.24 & 1.31 & 64.71 & 7 & $\begin{array}{l}\text { Neither } \\
\text { agree or } \\
\text { disagree }\end{array}$ \\
\hline & Sohar University & 3.31 & 1.36 & 66.27 & 4 & Neither \\
\hline
\end{tabular}




\begin{tabular}{|c|c|c|c|c|c|}
\hline $\begin{array}{l}\text { Department } \\
\text { Heads guide } \\
\text { subordinates to } \\
\text { work in the right } \\
\text { direction. }\end{array}$ & & & & & $\begin{array}{l}\text { agree or } \\
\text { disagree }\end{array}$ \\
\hline $\begin{array}{l}\text { Sohar University } \\
\text { Department } \\
\text { Heads identify } \\
\text { work priorities to } \\
\text { be achieved. }\end{array}$ & 3.25 & 1.38 & 65.10 & 6 & $\begin{array}{l}\text { Neither } \\
\text { agree or } \\
\text { disagree }\end{array}$ \\
\hline $\begin{array}{l}\text { Sohar University } \\
\text { Department } \\
\text { Heads explain } \\
\text { their achievements } \\
\text { to their } \\
\text { subordinates. }\end{array}$ & 3.51 & 1.33 & 70.20 & 1 & Agree \\
\hline $\begin{array}{l}\text { Sohar University } \\
\text { Department } \\
\text { Heads have the } \\
\text { ability to generate } \\
\text { enthusiasm, } \\
\text { commitment and } \\
\text { confidence in their } \\
\text { subordinates. }\end{array}$ & 3.43 & 1.33 & 68.63 & 3 & Agree \\
\hline
\end{tabular}

Table (E) shows the two highest items:

- Item (7) "Sohar University Department Heads explain their achievements to their subordinates", is in first place with a relative weight of $70.20 \%$.

- Item (3) "Sohar University Department Heads take advantage of the opportunities to upgrade the university", is in second place with a relative weight of $70.20 \%$.

The researcher attributes this to the fact that the department heads consider the employees as part of their achievements and take advantage of the opportunities to upgrade the university to achieve the desired goals.

\subsection{The lowest two items:}

- Item (4) "Sohar University Department Heads are keen to constantly encourage subordinates to do their jobs", is in seventh place with a relative weight of $64.71 \%$.

- Item (2) "Sohar University Department Heads set effective work standards", is in last place with a relative weight of $63.53 \%$.

The researcher attributes this to the little support having been paid to the employees and their need for effective work standards.

In general, it can be said that the respondents agreed to the items of this field. The department heads tend to apply inspirational motivation and take advantage of the opportunities to upgrade the university to demonstrate their achievements to their subordinates.

The researcher attributes this to the fact that the department heads influence their subordinates with inspirational motivation, encouraging them for teamwork through enthusiasm, idealism, competition, creativity and incentives.

In line with what's aforementioned, the results of the present study agree with (Searle \& Barbuto, 2013) in that inspirational motivation has a significant relative weight where inspirational motivation is in first place. In line with (Searle \& Barbuto, 2013, 
and Thomas, 2016), the results of the present study show that inspirational stimulation of transformational leaders reflects fruitful outcomes on their followers.

\subsection{Analysis of intellectual stimulation items:}

The arithmetic mean, standard deviation, relative weight and order were used to determine the degree of agreement.

\section{Results are shown in table (F).}

\section{Table (F)}

Arithmetic mean, standard deviation, relative weight, and order for each intellectual stimulation items

\begin{tabular}{|c|c|c|c|c|c|c|}
\hline No & Item & $\begin{array}{l}\text { Arithmetic } \\
\text { mean }\end{array}$ & $\begin{array}{l}\text { standard } \\
\text { deviation }\end{array}$ & $\begin{array}{l}\text { relative } \\
\text { weight }\end{array}$ & Order & $\begin{array}{l}\text { Degree of } \\
\text { agreement }\end{array}$ \\
\hline & $\begin{array}{l}\text { Sohar University } \\
\text { Department } \\
\text { Heads are keen } \\
\text { to present and } \\
\text { apply new work } \\
\text { ideas. }\end{array}$ & 3.35 & 1.31 & 67.06 & 3 & $\begin{array}{l}\text { Neither } \\
\text { agree or } \\
\text { disagree }\end{array}$ \\
\hline & $\begin{array}{r}\text { Sohar University } \\
\text { Department } \\
\text { Heads study new } \\
\text { ideas for } \\
\text { authenticity } \\
\text { before applying } \\
\text { them. }\end{array}$ & 3.25 & 1.35 & 65.10 & 5 & $\begin{array}{l}\text { Neither } \\
\text { agree or } \\
\text { disagree }\end{array}$ \\
\hline & $\begin{array}{l}\text { Sohar University } \\
\text { Department } \\
\text { Heads look for } \\
\text { new ways to } \\
\text { solve problems. }\end{array}$ & 3.61 & 1.25 & 72.16 & 1 & Agree \\
\hline & $\begin{array}{l}\text { Sohar University } \\
\text { Department } \\
\text { Heads } \\
\text { encourage } \\
\text { subordinates to } \\
\text { express their } \\
\text { opinions freely. }\end{array}$ & 3.35 & 1.35 & 67.06 & 2 & $\begin{array}{l}\text { Neither } \\
\text { agree or } \\
\text { disagree }\end{array}$ \\
\hline & $\begin{array}{l}\text { Sohar University } \\
\text { Department } \\
\text { Heads are keen } \\
\text { to motivate their } \\
\text { subordinates. }\end{array}$ & 3.29 & 1.46 & 65.88 & 4 & $\begin{array}{l}\text { Neither } \\
\text { agree or } \\
\text { disagree }\end{array}$ \\
\hline & $\begin{array}{l}\text { Sohar University } \\
\text { Department } \\
\text { Heads are keen } \\
\text { to encourage }\end{array}$ & 3.22 & 1.40 & 64.31 & 6 & $\begin{array}{l}\text { Neither } \\
\text { agree or } \\
\text { disagree }\end{array}$ \\
\hline
\end{tabular}




\begin{tabular}{|l|l|l|l|l|l|}
\hline subordinates. & & & & & \\
\hline $\begin{array}{l}\text { Sohar University } \\
\text { Department } \\
\text { Heads } \\
\text { encourage } \\
\text { innovation by } \\
\text { providing } \\
\text { solutions to work } \\
\text { problems. }\end{array}$ & 3.16 & 1.22 & 63.14 & 7 & $\begin{array}{l}\text { Neither } \\
\text { agree or } \\
\text { disagree }\end{array}$ \\
\hline
\end{tabular}

Table (F) shows the highest two items:

- Item (3) "Sohar University Department Heads look for new ways to solve problems", is in first place with a relative weight of $72.16 \%$.

The researcher attributes this to the department heads' use of the scientific method in thinking and solving problems, and in their use of innovative and modern methods to solve any problems.

- Item (4) "Sohar University Department Heads encourage subordinates to express their opinions freely", is in second place with a relative weight of $67.06 \%$.

The researcher attributes this to the fact that department heads actively encourage all employees to freely share their opinions with respect and hold sessions to present ideas and interventions.

\subsection{The lowest two items:}

- Item (6), which provided for "Sohar University Department Heads are keen to encourage subordinates", is in sixth place with a relative weight of $64.31 \%$.

- $\quad$ Item (7), which provided for (Sohar University Department Heads encourage innovation in providing solutions to work problems", is in last place with a relative weight of $63.14 \%$. The researcher attributes this to the fact that employees need to be encouraged since they may have great ideas not enough to take into consideration.

In general, it can be said that employees responded to intellectual stimulation, which was confirmed by (Thomas, 2016) that the degree of intellectual stimulation was high with a great relative weight. In addition, (Searle \& Barbuto, 2013) revealed that intellectual stimulation was of a great relative weight. (Thomas, 2016) concluded that the intellectual stimulation was of a great relative weight as well, as confirmed by (Bommer, Rich, \& Rubin, 2005)

\subsection{Conclusion}

Having conducted statistical analysis, this study draws some conclusions and suggests some recommendations for transformational leadership and its use in developing administrative creativity and improving job performance among Sohar University employees. This can be summarized as:

- Transformational leadership skills are very essential for high ranking leaders to acquire in Sohar University in the Sultanate of Oman.

- Transformational leaders with outstanding leadership skills are found astonishingly effective in managing and leading those working under them.

- Employees are found to be greatly affected by their leaders in respect with academic and managerial activities.

- The study found that Universities in the Sultanate of Oman do not pay special attention to transformational leadership skills, which this negatively affects the quality and credibility of teaching.

- The university requires innovation and creativity to improve job performance.

- Officials change periodically through student election.

- Involve students in making some decisions related to students' activities.

- There is a lack of teamwork spirit.

- Leaders should prefer collective work and thus prioritize the university interest over the personal interest.

- The employee is in need of his leaders' encouragement and confidence. 


\section{References}

[1] Ashforth, B. E., \& Mael, F. A. (1989). Social identity theory and the organisation. Academy of Management Review, 14, 20-39.

[2] Bandura, A. (2006). Toward a psychology of human agency. Perspectives on Psychological Science, 1, 164-180.

[3] Bandura, A. (2001). Social cognitive theory: An agentic perspective. Annual Review of Psychology, 52, 1-26.

[4] Bass, B. M., \& Avolio, B. J. (1993). Manual: The multifactor leadership questionnaire. Palo Alto, CA: Consulting Psychological Press.

[5] Bass, B. M. 1985. Leadership and performance beyond expectations. New York: Free Press.

[6] Bono, J. E., \& llies, R. (2006). Charisma, positive emotions and mood contagion. Leadership Quarterly, 17, 317-334.

[7] Bono, J. E., Foldes, H. J., Vinson, G., \& Muros, J. P. (2007). Workplace emotions: The role of supervision and leadership. Journal of Applied Psychology, 92, 1357-1367.

[8] Bommer, W. H., Rich, G. A., \& Rubin, R. S. (2005). Changing attitudes about change: Longitudinal effects of transformational leaders behavior on employee cynicism about organizational change. Journal of Organizational Behavior, 26, 733-753.

[9] Burns, J. M. 1978. Leadership. New York: Harper \& Row. Csikszentmihalyi, M. 1975. Beyond boredom and anxiety. San Francisco: Jossey-Bass.

[10] Burns, J. M. 1978. Leadership. New York: Harper \& Row. Csikszentmihalyi, M. 1975. Beyond boredom and anxiety. San Francisco: Jossey-Bass.

[11] Burns, J. M. (1978). Leadership. New York: Harper \& Row.

[12] Bommer, W. H., Rich, G. A., \& Rubin, R. S. (2005). Changing attitudes about change:

Longitudinal effects of transformational leader behavior on employee cynicism about

organizational change. Journal of Organizational Behavior, 26, 733-753.

[13] Breevaart, K., Bakker, A. B., Demerouti, E., \& Derks, D. (2016). Who takes the lead? A

multi-source diary study on leadership, work engagement, and job performance. Journal of Organizational Behavior, 37, $309-325$.

[14] Caillier, J. G. (2014a). Do transformational leaders affect turnover intentions and extra-role behaviors through mission valence? American Review of Public Administration, 46, 226-242.

[15] Caillier, J. G. (2014b). Toward a better understanding of the relationship between transformational leadership, public service motivation, mission valence, and employeeperformance: A preliminary study. Public Personnel Management, 43, 218-239.

[16] Colbert, A. E., Bradley, B. H., \& Barrick, M. R. (2008). CEO transformational leadership: The role of goal importance congruence in top management teams. Academy of Management Journal, 51, 81-96.

[17] Ekvall, G., \& Arvonen, K. (1991). Change-centered leadership: An extension of the two dimensional model. Scandinavian Journal of Management, 7, 17-26.

[18] Fuller, J. B., Patterson, C. E. P., Hester, K., \& Stringer, D. Y. 1996. A quantitative review of research on charismatic leadership. Psychological Reports, 78: 271-287.

[19] Grant, A. M. (2012). Leading with meaning: Beneficiary contact, prosocial impact, and the performance effects of transformational leadership. Academy of Management Journal, 55, 458-476.

[20] Greenleaf, R.K. (1977). Servant leadership: A journey into the nature of legitimate power \& greatness. Mahwah, NJ: Paulist Press.

[21] Harrison, D. A., Newman, D. A., \& Roth, P. L. (2006). How important are job attitudes? Meta-analytic comparisons of integrative behavioral outcomes and time sequences. Academy of Management Journal, 49, 305-325.

[22] Hornsey, M. J., \& Hogg, M. A. (2000). Assimilation and diversity: An integrative model of subgroup relations. Personality and Social Psychology Review, 4, 143-156.

[23] Hirst, G., Van Dick, R., \& Van Knippenberg, D. (2009). A social identity perspective on leadership and employee creativity. Journal of Organizational Behavior, 30, 963-982.

[24] House, R. J., \& Shamir, B. (1993). Toward the integration of transformational, charismatic, and visionary theories. M. M. Chemers, \& R. Ayman (Eds.), Leadership theory and research: Perspectives and Direction, (pp. 81-107). San Diego, CA: Academic Press.

[25] Herold, D. M., Fedor, D. B., Caldwell, S., \& Liu, Y. (2008). The effects of transformational and change leadership on employees' commitment to a change: A multilevel study. Journal of Applied Psychology, 93, 346-357.

[26] Hackman, J. R., \& Oldham, G. R. 1976. Motivation through the design of work: Test of a theory. Organizational.

[27] Howell, J.M., \& Avolio, B. J. (1993). Transformational leadership, transactional leadership, locus of control, and support for innovation: Key predictors of consolidated business- unit performance. Journal of Applied Psychology, 78, 891-902.

[28] Judge, T. A., \& Piccolo, R. F. 2004. Transformational and transactional leadership: A meta-analytic test of their relative validity. Journal of Applied Psychology, 89: 755-768.

[29] Lowe, K. B., Kroeck, K. G., \& Sivasubramaniam, N. 1996. Effectiveness correlates of transformational leadership and transactional leadership: A meta-analytic review of the MLQ literature. Leadership Quarterly, 7: 385-425.

[30] Maslow, A. H. (1954). Motivation and personality. New York: Harper and Row.

[31] Menges, J. I.,Walter, F., Vogel, B., \& Bruch, H. (2011). Transformational leadership climate: Performance linkages, mechanisms, and boundary conditions at the organizational level. The Leadership Quarterly, 22, 893-909.

[32] McGregor, D. M. (2003). The human side of enterprise. New York: McGraw-Hill.

[33] Nemanich, L. A., \& Keller, R. T. (2007). Transformational leadership in an acquisition: A

field study of employees. The Leadership Quarterly, 18, 49-68.

[34] Oreg, S., \& Berson, Y. (2011). Leadership and employees' reactions to change: The role of leaders' personal attributes and transformational leadership style. Personnel Psychology, 64, 627-659.

[35] Ohly, S., \& Schmitt, A. (2015).What makes us enthusiastic, angry, feeling at rest or worried? Development and validation of an affective work events taxonomy using concept mapping methodology. Journal of Business and Psychology, 30, 15-35.

[36] Pratt, M. G., \& Ashforth, B. E. (2003). Fostering meaningfulness in working and at work. In

Positive organizational scholarship: Foundations of New Discipline: 309-327. San Francisco: Berrett- Koehler. 
[37] Piccolo, R. (2006). Transformational leadership and job behaviors: the mediating role of core job characteristics. Academy of Management Journal, 49(2), 327-340

[38] Salancik, G. R., \& Pfeffer, J. 1978. A social information processing approach to job attitudes and job design. Administrative Science Quarterly, 23: 224-254.

[39] Searle, T. P., \& Barbuto, J. E. (2013). A multilevel framework: Expanding and bridging micro andmacro levels of positive behavior with leadership. Journal of Leadership and Organizational Studies, 20, 274-286.

[40] Smircich, L., \& Morgan, G. 1982. Leadership: The management of meaning. Journal of Applied Behavioral Science, 18: $257-273$.

[41] Thomas, N. (2016). Transformational leadership and performance outcomes: Analyses of multible mediation pathways. The Leadership Quarterly, 20(3), p.15-33

[42] Vignoles, V. L., Regalia, C., Manzi, C., Colledge, J., \& Scabini, E. (2006). Beyond self-esteem: Influence of multiple motives on identity construction. Journal of Personality and Social Psychology, 90, 308-333.

[43] Yukl, G. (1999a). An evaluation of conceptual weaknesses in transformational and charismatic leadership. The Leadership Quarterly, 10(2), 285-305.

[44] Weiss, H. M., \& Cropanzano, R. (1996). Affective events theory: A theoretical discussion of the structure, causes, and consequences of affective experiences at work. Research in Organizational Behavior, 18, 1-74. Vroom, V. H. (1964). Work and motivation. New York: Wiley. 